\title{
無常を説くマニ教ソグド語文書
}

一一京都大学文学部所蔵の写真資料から—

\section{On a Manichaean Sogdian Fragment Expounding Vanity of Earthly Life}

_ Text preceding Henning's 'Job Story' _-

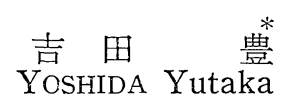

ABSTRACT In this article one Manichaean Sogdian fragment is edited. Two old dry plates of the fragment, which was further broken into two pieces, are preserved at the Department of Oriental History, Kyoto University. Although the present whereabouts of the original is not known, circumstances suggest that it once existed in Japan, and that the photographs were made for the late Professor Toru Haneda of Kyoto University, who had a reputation of being a good decipherer of old manuscripts unearthed from Central Asia.

From its contents and handwriting it can be proved that the fragment immediately precedes the so-called "Job Story" published by W. B. Henning ( $B S O A S 11,1945,485-87$ ). The combined text spends all 50 lines (11. 28-50 being a 'Job Story') expounding vanity and impermanence of earthly life and bears strong similarity to the "lament for impermanence" found in the Chinese Manichaean hymnscroll 11. 83119. One excerpt will illustrate this. Compare the following Sogdian passage with line 102 of the hymnscroll.

(26) ... rty cnn $Z K w$ pryw $Z Y$ cnn šyrxwz-'k $Z Y Z K$ (27) xwtm wxsty c'nkw ZY ZK r'och ZY ZKw (xw'kkr'k?) ky ZY kßnh (28) (')z-mnw " wx'n'yt 'skw'nt $Z Y Z K w$ 'nw'stk rty pts'r yxw'y'nt (29) (x)w 'yw cnn

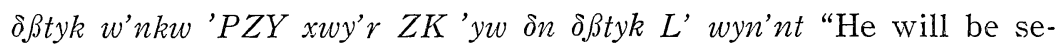
parated from his loved ones, friends and relatives like travellers and merchants who stay together for a little while under the same

* 神戸市外国語大学助教授

Associate Professor, Kobe City University of Foreign Studies 
roof, but later separate from each other so that they do not meet each other easily.”

世諦暫時諸親参／豈殊客館而寄住／暮則衆人共止宿／旦則分離帰本土“The temporal relations of a family, which are mundane truth, How far do they differ from that of staying at a traveller's inn? Masses of persons stop and rest together for a night; In the morning, they separate and return to their own lands", cf. Tsui Chi, BSOAS 11, 1943, 185.

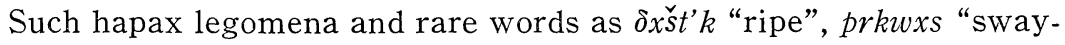
ing", and 'pw ptspnyh "vanity?" found in the text make the fragment intriguing also from the philological point of view.

\section{○.はじめに}

京都大学文学部東洋史学科には, 筆者が知る限り 3 種類のソグド語資料が保 管されている。第 1 のもは，モンゴル高原にあったカラバルガスン碑文の拓 本である。これについては既に先の存在を報告して打いた。これは跋文から羽 田亭が言及する，「三田氏が蒙古に在任中，人をして作らしめたる拓本」の一 部であることが分かる。残りの部分は, 現在立命館大学に保管されているらし い。これとは別に，ソグド語文書の現物 1 点と写真資料がある。本稿ではとの らちの写真資料についての研究を発表する。前者はトルファン出土で, 『涅槃 経』のソグド語訳断片であるが，紙数の関係でここに含めることができなかっ た。いずれ稿を改めて発表したいと考光ている。貴重な資料の公開を快諾され た, 京都大学東洋史学科の永田英正教授及び関係者に感謝する。

\section{I. 文書の由莱と体裁}

京都大学の東洋史学科が保管する古いガラス板の写真資料のなかに，2 点ソ グド語の文書の写真が含まれている。これらの写真が，どのよらな経緯で同学 科の所蔵に鹵したかの詳細は不明であるが，非常に古い写真であることと，同 研究室でかつてこの種の文書を研究していた研究者は多くないことから判断し て，故羽田亭博士が入手したものに相違ない。内容を検討すると，これらの 2 点は同一文書の離れであり互いに接合することが分かる。しかもかつて W. B. Henning が研究し発表した，ドイッ・トルファン探検隊将来の文書とも接合 
することが明らかになった。

羽田亭が戦前に，ベルリンにある未発表のソグド語文書の写真を入手し得た とは考光られない。また Henning のよらな研究者が，ベルリンにあった関連 の資料を見落としていたことも考光にくい。それ故，ここに発表する2 点（実 際には 1 点の 2 断片）の現物は, ベルリンにあったのではなく, なんらかの経 緯で日本に入ったものと推測される。同研究室が保管する『涅槃経』の断片の ように中国人の手を介して日本に入ったのかもしれないし，大谷探検隊の収集 物が，私的に売り出されていたのかもしれない。今となっては知るすべがない。

Henning はこの文書の離れを発表したとき，残された部分の内容からマニ 教徒が用いた説話の断片と考皇た。そして“Job Story’ と名付子て，マニ教 ソグド語の説話に関する論文のなかにこれる含めた。ここで扱う断片はこれに 直接先行する部分である。しかも内容を検討してみると，全体はこの世の無常 を説ぐもので，いわゆる説話ではないことが分かる。この世の無常を説くとい ら点では, 敦煌出土の漢訳マニ教文献『摩尼経下部讃』（スタイン本：S 2659, 『大正大蔵経』第54巻，1270-79所収）の83-119行にある「歎無常文」とよく似 (8) ている。下でも論じるように，いくつかのモチーフは同じであり，両者が無関 係であったとは考党られない。

ここで発表する資料は写真であるから，文書学的情報は得られないが，筆者 は1992年秋にベルリンの Staatsbibliothek で, Henning が発表した文書の 実物を調查する機会があった。TiiD といら旧編号とは別に，現在は So 13400 の番号が与えられたこの断片は，横 $25.3 \mathrm{~cm}$ 縦 $31.7 \mathrm{~cm}$ の大きさで, 漢文仏 典の紙背を利用して書かれている。漢文仏典は『妙法蓮華経』(『大正』第 9 巻，61頁 a 21-b 12）である。筆者の印象では，字体と紙質から 7-8 世紀の ごく普通の写本であるように思われた。これは同様にトルファンで出土した， 漢文仏典の紙背を利用したマニ教文献について言觉ることである。従って，ソ グド文の活うはそれ以降，9・10世紀頃のものと考えてよいであろう。な和京 大の写真資料とベルリンの文書を接合すると，全体で50行のテキストを回収で きる。そのうち 28-50 行が，Henning によって発表された部分である。

写真版からも明かなとおり，ここに発表する文書では，特に右端の部分の破 損が著しい。単に紙が破れているだけでなく，表面がこすれて文字が読めなく なってもいる。従って多くの場所で満足のゆく読みができず，不明の箇所を残 
したまま発表せざるを得ないのは残念である。

II. テキストと翻訳

$$
\text { テキス } \stackrel{(11)}{ト}
$$

$1[\quad]()$.$y ZY nyst Bntk'ma c'nkw ZY ZKn (s'ty) { }^{\mathrm{b}}$ xwyr ZKw

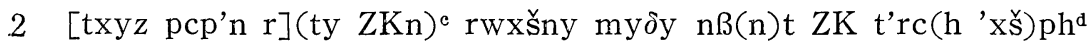
ZY

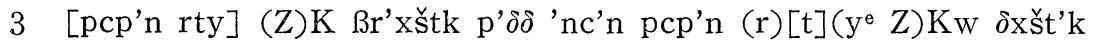

4 [Br'k ZK] (pr)kwxs ZY ZKw 'wr'yz pcp'n rty ZK rr'yk'yny $\gamma \mathrm{w} \delta^{\prime} \mathrm{k}$

5 [ptšk'ß] pcp'n myo 'wyn wyspny w'to'r ZKh m(rch pcp'n)

6 [rty ](. ') ywp't ZKh wyšn kwyšt ZKh r't ZY 'xšywn'y(t)

$7 \quad[Z Y \quad x w]\left(t^{\prime}\right) w t \quad Z Y$ ms 'nyw $\gamma r ß w$ znk'n mrtxm'yt ky ZY pr'ymy $\delta$ 'Bc'm-

$8[\mathrm{p} \delta$ 'x] (šy)t'ntg ZY nwš'yt L' 'krt'nt p'rZY 'kw "y'm ZKw mrc

9 (m) $[\mathrm{y}](\delta) \mathrm{y}^{\mathrm{h}} \mathrm{ZKw}$ wyspw mrtxmy prw šyr'krtyh ZY pr pwrny'ny'kh $(\ldots . .5)^{\mathrm{i}}$

10 [ ] (c'tj rw'n'yt $t^{\text {k }}$ 'krt'nt $\left.r t\right) y$ cnn 'ky prnxwnty m't rty k $\delta^{\prime} r t$

11[

$12^{\mathrm{n}}[$

13[

$14 \quad[$

15 [š't'wxy'kh?

16 ZY ßn's rtš(w) 'kw "y'm moy pr' $\gamma t \delta(' r ' n) t$ rty nw-ryz-y ZY $(\text { prw) })^{p}$

17 pwz-kßty rty xwty xrt'nt rty 'M mrcy pr'w L' rnß't 'kó'r'nt

18 p'rZY mwrt'nt ZY nyst 'krt'nt o rty kory nwkr c'nkw nyw'nt

$19[\gamma]\left(n t^{\prime} k\right) r^{\prime} k^{q}$ ZY ZKn nw-wrn'k mrtxm'k ky ZY ZKw šyr'krtyh L'

20 [kwnty] rtšw L' ZKh rw'ny-mynch 'rkh wrnty rtšy 'cw

$21[\quad]($.$) ZKn xyp \delta$ r'yw nwš'k šm'rt rtšy kt'r ZKwy m'ny 
w'nw

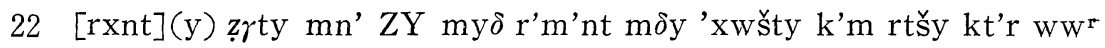
23 ßz-ny s'št Brt nyw'nty ky ZY m'n'kh 'pw ptspnyh nyß'x šs o

24 rty $\mathrm{k} \delta$ c'ß kwny rtšw prz-r'm 'y $\delta \mathrm{cw}$ 'np'r nyst pwtkr'y ZY

$25\left[\stackrel{\text { š }}{2}\left(\mathrm{yrw}^{\mathrm{t}} \beta^{\prime}\right)\right.$ rrn'k šyr'k $\delta \beta^{\prime} r \mathrm{ZY} Z \mathrm{KW}$ pry’npr'ytm ' $Z$-wnh ckn'cw 26 ZY šw $\delta$ ßtyw zyt'k ßwtu rty cnn $Z K w$ pryw ZY cnn šyrxwz-'k ZY ZK

$27^{v}$ xwtm wxsty c'nkw ZY ZK r'och ZY ZKw (xw'kkr'k)w ky ZY $\mathrm{kBnh}$

$28^{x}$ (') $z-m n w^{y}$ ' 'wx'n'yt 'skw'nt ZY ZKw 'nw'štk rty pts'r yxw'y'nt 29 (x)w 'yw $\delta 3 t y k$ w'nkw 'PZY xwy'r ZK 'yw $\delta n^{z} \delta \beta t y k$ L' wyn'nt

`Bntk’m は c’nkw の上に書き足されている； ${ }^{b}$ 読みに関しては注釈参照; ${ }^{\mathrm{c}}$ 文 字の下部のみ。読みは不確実：“初頭の’は奇妙な形をしている。表面が破損 したからか； ${ }^{\mathrm{e}}$ と読んだ文字は奇妙な形で，及のよらに見える； ${ }^{\mathrm{f}}$ 尻尾の長い 文字で終わっている。t, k, p などが可能である; $\mathrm{g}(\mathrm{s} y)$ の部分は破損して括り， 読みといらより復元である： $\mathrm{h}[\mathrm{y}]$ のスペースはないかもしれない。その場合

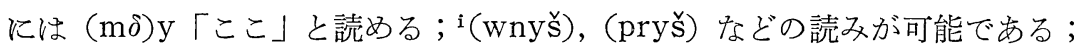
j 他に（wnt)，(p’t）などの読みが可能である；k文字の上部のみ。読みに関 しては注釈参照; ${ }^{1}$ 最初 šyrxw と書いて䛊りに気付き，書き直したもの; ${ }^{m} \mathrm{yxwy}-\mathrm{t}[\mathrm{y}]$ とも読めるが，この付近は動詞がみな過去形であるのでこう読ん だ。実際この文書では文字 S はやや奇妙な形をしている； ${ }^{n} 12$ 行目は 2 つ断 片に分かれている。(ZKw) の文字の下部は一方の断片にのみ残されている; 表面がかす机ていて，長い屟尾だけが確実である； p文字の上部のみ； q文字の

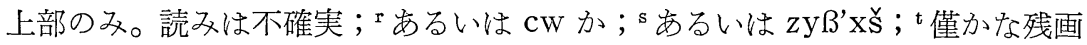
のみ。読みは不確実; ${ }^{\mathrm{u}}$ 最初 Bnt と書いて, 後にnの上に $\mathrm{n}$ を書いている; この行のほとんぞは京都大学の文書に残されていて，ベルリンにある断片には 文字の下部だけしか見觉ない; “文字の上部だけが残されており，読みは必ず しも確実ではない。 $\mathrm{xW}$ 'kr' $\mathrm{k}$ も可能; “ Henning のテキストはここから始ま る。意味のつながりからは29行目で段落が終わるので, 便宜のためにこの 2 行 もここに含めることにした； ${ }^{\mathrm{B} H e n n i n g}$ は $\mathrm{z}$-mnw と読さが， $z$ の前に 1 字分 


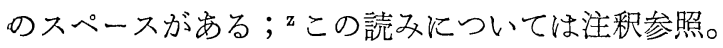

(12)

訳

「……としてなくなってしまらだろら。ちょうど登った太陽に〔沈むことが 目前〕であるように; 明るい昼のとばに暗い夜が[目前〕である（ように）；放 たれた矢に静止が目前である（ように）；熟れた[果物】がぶらぶらし（ついに は）落ちてしまうことが目前である（ように）；泥でできた螜に ${ }^{5}$ [砕けること が】目前である(ように)。ちょうどそのようにすべての生き物に死は目前で 岁る。

……つてこの世を支配していた巨人，王，支配者，首領，及び他の多くの 種類の人々は，常住なるものとはならず，最後の死の日には，すべての人々に 対して，善行と功德により，魂が $10 \cdots \cdots$ …をなっ。そして彼らのうちで幸運で， …………世間的な富から離孔……[する者は, ] 常住の富と永遠の財を[獲得 し?]かぐわしい天国で[暮らすことになった。] しかし一方，…‥せず，…... 北関して心穏やかでなく，肉体的 ${ }^{15}$ [喜び] ……種々の誤った教觉や虚偽〔に よって財を為した者は？，」最後にはそれ（=この世で貯めた財宝？）学，嫌 々ながら仕方なくこの世に残した。そして自分自身は行き，死とは争そうこと ができず死んで，存在しなくなってしまった。

さて今，悪行の不信心の人で，善行を[行わ]ず，20魂のための仕事という ものを信用しない人。もし(その人が)……自分の身体を常住と見なすなら，そ の者はあるいは大胆にも心の中で「私の日はここではいつも増大する」と思う か，あるいはまたこの無益（／無常）なるのを与えた人に感謝しなければなら ないことになる。そしてその者はどれほど多くのことをしても，決して満足す ることはない。すばらしい贈物や最愛の子供も，有害で ${ }^{25}$ るもはかない。そ れらは再び取り上げられることになるからである。そして愛する者や友人，血 縁からも引き離される。ちょうど旅人や商人が，しばらくの間は同じ屋根の下 に集らが，後には互いに別れ別れになり，再び会うことが容易ではないように。

\section{III. 訳 注}

1-5 この部分ではこの世にあるもののはかなさが，いくつかの比喻によ って説明されている。上述した「歎無常文」では特に 87-89 行に，そのことが 
詳しく論じられている。それによれば，この世の一切はまるで砂漠で見る愿気 楼のようなものであり, この世の栄華は風炕吹き飛ばさ㣗る雲のようであり, 肉体は春の草花がいつまでも青くなく，結局は枯れてしまうようなものだとい 亏。

1 (s'ty): 最初の文字 $\mathrm{s}$ の読みには不安が残る。もののはかなさの比喻と して太陽が用いられるとすれば，登った太陽がすぐに沈むことだと考光，この ように復元した。動詞 sn- の過去語幹は st-であり, s'ty の綴りは奇妙だが, 短い母音 [a] が文字’によって表記されることは珍しくない。GMS 114 参照。

2 [txyz pcp'n]：未発表のマ二文字資料（M4551）飞, xwr m'xy[y] txyyz pcp'n とあり，この復元が正しいことがわかる。txyz の前にさらに m’x 補らスペースはないよらに見光る。な特 M4551 のテキストは，熊本裕 教授潈贈された故 Dresden 教授のノートから引用した。この部分の一部は GMS § 1639 飞も引用されている。

$2 \mathrm{ZY}$ : 行末の ZY はしばしば埋め草として用いられる。これも歽で ある。

3 oxšt'k：これは初出の形式であるが，コータン語の dișța- と同源で, 「熟れた」を意味する語であろら。破損部に Br'k「果物」を補らと，後続の 'wr'y $\boldsymbol{Z} \Gamma($ 果物が木から) 落らる」とよく合ら。ところでングド語には「(穀物 が）実る」を意味する $\delta$ Xs-といら動詞の現在語幹が在証されて特り，この動 詞と dxšt'k がどのよらな関係にあるかが問題である。同じ語根に由来する動 詞と形容詞かもしれないし，後者が前者の過去分詞であるかもしれない。コー タン語では，前述の形式は現在語幹 daj-の過去語幹であるので，後者の可能 性が高い。別のマ二教文献によれば，天国では，実を結ぶ樹木は常に青々とし ていて，その果物は落ちも腐りもせず，虫も付かないといら。Henning, BSO; AS 12, 1948, 307 参照。

4 (pr)kwXs : これも初出の語である。熟れた果物が落ちることが問題に なっているといら筆者の前提が正しいならば，これは落らる直前の果物の有様 の表現であることになる。ところでソグド語には ākōč/ākurt「つりさげる」 及び ptkwc/ptkwrt「釣る，針でひっか子る」といら動詞が知られており， それらから語根 *kauč-「つりさげる」を抽出できる。 prkwxs はこの語根と は無関係ではあり得ず，その語源として *pari-kuxsa- あるいは*fra-kuxsa- 
を想定できるであろら。つまりいわゆる inchoative 形の動詞現在語幹から派 生した動名詞で，意味は文脈から考劣て「ぶらぶらすること」であったと思わ れる。同じく inchoative 形から派生した名詞に 'ntwxs「努力」があり参考 になる。

5 [ptšk'B]：焼物の螜が砕けることが問題になっているに違いない。螜を 壊す動作を動詞 ptšq'f によって表現している例があり，仮にこのよらに復元 した。

6-18 過去の人々で，生前に善行を積み天国に行った者と，悪行をなして 死に無に帰した者についての説明である。最初のほうでは行の初めのかなりの 部分が失われていて，細部を知ることができない。終わりのほうでは行はほぼ 完全に残されているが，ここでも必ずしも意味内容は明かではない。さらに過 去の人々の筆頭に，巨人や王様があげられている理由も筆者には不明である。

6 'ywp't：通常「一度」を意味するこの語は，「かつて」の意味で用いら れる場合がある。例えば P 9,78 を参照せよ。

$6 \mathrm{r}$ ”t：サンスクリットの rājan一「王様」から借用された語である。P 7, 26 に rwk'yntr r't (く Lokendra-rāja-) が見える。またサンクト・ペテル ブルグにある未発表のソグド語文書（SI : KrIV/862）にも，r’t といら形式が 在証される。同じ断片の m'ywr 'xšywn'yt「孔雀王」を参考にすれば，こ れも「王」を意味する同じ語であろら。

9 pwrny'ny'kh：奇妙な経りだが，マ二文字で在証される pwrny'nyy' のソグド語文字による表記である。

10 [ ] (c't rw'n'yt)：復元は必ずしも確実ではない。特に最初の部分 にはいくつもの読みが可能である。ここでは rw'nを後分とする bahuvrinhi 複合語（「〜な魂を持つ」）の複数形とみなした。巨人その他が死に際して, 善 行や功德を積んだ人々を羡ましく思らことが問題になっていると考えたが確信 はない。あるいは彼らが生前の功德によって, 再生しやり直す機会が与えられ たことを言っているのだろらか。

15 [znk]znk'n-'k : キリスト教ソグド語の zng zng'ny を参照せよ。これ は F. W. K. Müller and W. Lentz, Soghdische Texte II, SPAW, 1934, Nr. 21, 518, line 76 在証される。

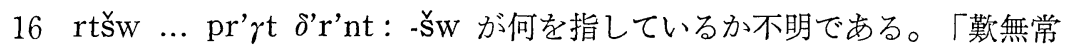


文」（92行）には「積聚一切諸財宝／皆由悪業兼妄語／無常之日並悉留／仍與 明性充為杻」とあり，この世で賗めた財宝は死んだ時に，この世に残していく ことになると言っている。それと関連づけてここを解釈した。あるいは，悪人

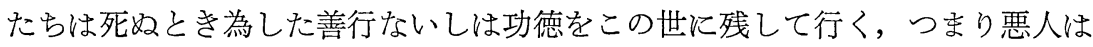
生前汇善行を積んでも，それを死後携光て行くことができないことを説いてい るのだららか。

17 prw pwz-kßty「無理やりに」：この語を正しく読み，マ二文字で pwskfty そ綴られているのと同じ語であることを指摘したのは Sims-Williams 教授である。Henning は pwskfty を “under constraint”と訳したが，そ の訳は nw-ryz-y「嫌及ながら」と共起するこの文脈沈よく合ら。ただし語 根 skamb「抑制する」から派生しょうとする Henning の語源や，kamp「曲 ゲる」に由来するとする Gershevitch の説は，ここの形式の -z- と矛盾す る。有声音が $\mathrm{k}$ の前で無声化したと考光る方が自然であるからである。しかし 今のところ筆者には交替案がない。

$17 \mathrm{rn \beta}$ 't : この語は最初「争う, 攻撃する」と訳されていた。その後 M. Schwartz は, ソグド語文献 P 2, 326 及び P 3, 183-91 の rnß とコレズム 語の rnf-を同じ語源の語と見なした。そしてコレズム語の例が文脈から「交 尾する」と解釈されるから，これらの語は「交尾する，性交する」と訳すべき であるとした。彼の説はコレズム語関する限り, 一般に受け入れられている。 しかし P 2 の例はいかゆる浄肉の説明で, 殺害によらない10種類の肉を解説す るなかの 3 番目である。第 1 亿老衰, 次に病気で死んだものをあげ, 次に互い 飞 $\mathrm{rn}$ し死んだものの肉, さらに 4 番目には水死したるのが列挙されている。 この文脈から $\mathrm{rnB}$ が「交尾する」を意味すると考兄ることはできない。

また Schwartz は言及しないが, 別のソグド語仏典飞, 'M zn'kh z'wr rnß'y「知の力をるって $\mathrm{rnB}$ し...…」といら一節があり,ここでも「交尾する」

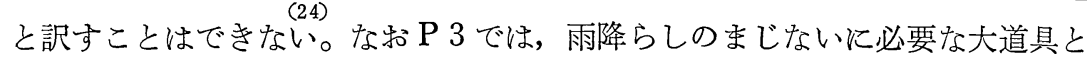
して，作製すべき彫刻の造形が説明されている。そして同じ種類の動物どらし が rnßする様子を表現するよう指示されている。この文脈からは，「交尾す る」る「争う」る可能である。以上を要するに, ソグド語の $\operatorname{rn} ß$ は「争う」を 意味し「交尾する」と翻訳することはできない。無論本文書に淤ける例でも， 死と $\mathrm{rnB}$ できないというのであるから，「交尾する」ではあり得ない。コレ 
ズム語の例では，原文のアラビア語の表現 safada は確かに「交尾する」を意 味するが，ペルシア語版では bar-jast「飛びかかる」となっていて，必ずしも 「交尾する」を意味しなかった可能性もある。

18一23 この部分では, 個々の語の解釈にほぼ問題はないが，各部を構成す る文のつながりがよく分からない。特に kt’r で始まる部分が分かりにくい。 従って筆者の翻訳もとれを反映して，内容の不明膫なるのになっている。な特 筆者は，18行目の c'nkw「〜するとき」で始まる節は完結せず，20行目の 'cw 「もし」で始まる節に受け継がれていると考光た。つまり20行目の šy は，長 い名詞句 nyw'nt ... wrnty を指示しているものと解釈した。

20 rw'ny-mynch : rw'nmynch が期待される。敊そらく rw'n の斜格形 を書いてから，思い直して接尾辞 - mynch を添光たのであるう。

21 ZKwy m'ny w'nw [rxnt](y) zrty：zrty は不定詞なので, これを 支配する動詞が先行するはずである。過去不定詞を支配し破損部を満たし得る 軽語幹 (light stem) の動詞としては, rxn-があるのでこのように復元した。 ただし必ずしる文脈から期待される意味は得られない。

23 Bz-ny s'št Brt: Bzn-「感謝 (の心)」に関しては拙稿 (Studia Iranica 13，1984，148-49）参照。な特とこでの筆者の解釈は，後に漢文原典が比定さ れることにより証明された。

23 'pw ptspnyh：初出の表現である。キリスト教文献飞 ptspyn-「有益 である」といら動詞があり, それと無関係ではあり得ない。 ptspnyh は, 形 容詞 *ptspn- から派生した抽象名詞であろら。無益なものとは, 富や名声な ぞのこの世和牧る繁栄のことであらら。一方, 問題のキリスト教りグド語形 の意味る，十分確定しているわけではない。一度しか現れず，乞こでの文脈は 結局は ptspyn-しないこの世の財産を捨てよ, と言っている。つまり「役に 立つ」以外飞，「長続きする」の訳も可能である。もしそちらが正しいなら， 'pw ptspnyh は「無常」と翻訳できる。

23 ny $\beta^{\prime} \times s ̌$ : 従来知られていない動詞 *nß'xš- の未完了形であると考光ら れる。動詞 Bxš-「分け与克る」にはこれまで pr- 及び'n-が付加された例し か知られていなかった。 $\mathrm{n}(\mathrm{y})$ - (く OIr. *ni-) を伴ら例は, 他のイラン系の言 語にも知られていないようである。無論 zyß’x が付加されたるのと考光ることもできる。 


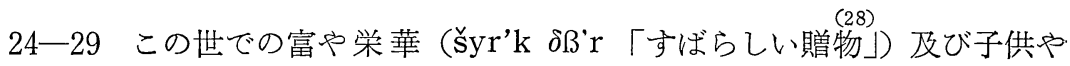
友人が，結局は離ればなれになり頼りにならないことを説いている。財産や栄 華のはかなさは，「歎無常文」の88，92，96，117行目に，子供や親族の頼りな さは，98，102，103，116行目に論じられている。るたこの部分の内容は， Henning がかつて発表した TM 393 （=So 18248）の recto 1-15にも酷似し (29) ている。

24 pwtkr'y : これも初出の語である。ただし Sims-Williams 教授が筆者 あての手紙で指摘されたよらに，従来気付かれてはいないがムグ文書にも在証 されている: 'zw w'nkw $\gamma \mathrm{r} ß$ 'm c'-pwtkkr'y-st ZY trw 'y-š (B-18, 3-4) 「私は扮まえがあまりに役立たずであることを理解している」。関連する語には キリスト教文献の pwtqy「破壊，崩壊？」及び，仏典の「大殊禍」に対応する pwt'k がある。語根 *pū 「腐る」に由来することは明かであるが，その過去 分詞が持っていた意味の広がりを正確に知ることは難しい。ここでは pwtkkr'y は，「役に立たない，不利益を為す」の方向の意味を持っていた考觉た。 pwtqy p pwt'k もとの方向で解釈できるかもしれない。

25 B'r rn'k：これも初出の語だが，P 2，1158-59に次のような一節がある： 'pw "st'nyh B'rrn CWRH 'nwtyh L' 'skwy「無常で......な身体に頼って はいけない」。’r rn は先行する 'pw ”st'nyh と類義語であるに違いなく， 「はかない」と翻訳できよう。その意味はここの文脈にもよく合う。意味の点 では接尾辞 -'k の有無は無関係であろらが, 筆者には B'r r n の語源は不明で ある。

26 ZY šw ... zyt'k ßwt: 動詞 zyn/zyt「奪う」は, wyšnd fryštyyt

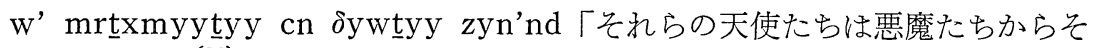
の人々を奪った」のように，「AをBから（cn B ）奪う」という構文になって いる。一方受動態では zytyy B’t cn r Btyy rmbnyy 「彼は苦労し(て得) た労苦 (の結果) を奪わ机るだろら」のように,「BはAを（cn A) 奪われる」 といら構文をとる。つまり奪われる人にも物にも前置詞 cn が付加され得た。 この構文の曖昧さから, 本来不必要な Šw が添えられたのであろら。

$27 \mathrm{xw} k \mathrm{knr}$ 'k: 読みに不安は残るが，「商人」を意味する語は確かに文脈か ら期待される。ちなみに「歎無常文」の次の一節（102行）は，この部分と非 常によく似ている：「世諦暫時諸親春／豈殊客館而寄住／暮則衆人共止宿／旦 
則分離帰本土」

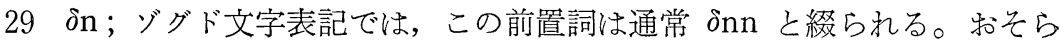
く後続の L’に影響された誤写であろら。

\section{Job Story}

上述したよらに 28-50 の部分は Henning によって既に提出されて和り，こ こに改めて発表する必要はない。30行目以降は24-29行目で説明されたことを 具体例で示している。その具体性から説話の一部と誤解されたのであろら。な 特 Henning によって提出されたテキストと翻訳には，わずかではあるが，そ の後の研究により改善できる点や，異なる解釈や読みを提案できる箇所がある ので，下ではそれらを列挙して扰くことにする。便宜のために，接合後の文書 の行数だけでなく, Henning のテキストの行数も与えておいた。

39/12 : 'stwrp $\delta$ 'k (H[enning]), 'stwrp $\delta \mathrm{k}$ (Y[oshida]). 確か飞 $\delta$ と k 間には 1 文字分の間隔はあるが，文字’のストロークが見光ない。後で書き足 したものがかすれてしまったのかもしれない。

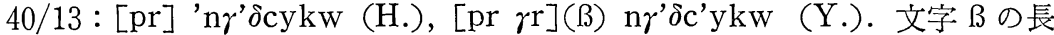
い尻尾の一部が見觉る。さらに prを補らスペースもある。H．も指摘すると特 り，後続の ”Bryncykw の上には本文とは異なる手による書き达みがある。 H. は pš...w と読んで「Wを挿入せよ」を意味するメモと解釈した。最後の w に関してはその解釈が正しいことは明かであるが，先行する部分については pr rrß と読み, pr rrß ”Brywncykw と読まそうとしたものと解釈できるか もしれない。ただし $\mathrm{p}$ 以外は個々の文字を確認できないほど乱雑に書かれてい る。

41/14: [...].m'yt (H.), [mrt](x)m'yt (Y.).「町全体で, 人々の間で」と 訳され，文脈からも支持される。

42/15 : […]r (H.), [yw']r (Y.). 当時 H. は yw'r「別れること」を「悲 しみ」を意味するものと誤解していた。BSOAS 12, 1948, 310 参照。rtynwkr pts'r Bwt ZY ryrtr ZY [yw’]r cnn z't’yty ... はやや奇妙な構文だが， 2 番目の ZY は埋め草であり，「そしてそれから息子たちから別れることにな り……」と翻訳される。

43/16: [yxw'yt ZY tr] 'z-mnyh (H.), [rt](pts'r ZKwy) 'z-mnyh 
(Y.).注とんどが破損しているので，いずれにしても不確実な復元を提案する 意味はないが，42行目で [yw’ $] \mathrm{r}$ を想定すれば，当然この部分の復元も变更し なければならない。

44/17: [...]xs'nt (H.), ['”r]xs'nt (Y.). この行の yw'r の意味が明らか

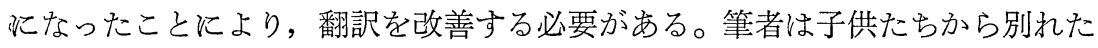
この男が，別離していない人 (nyw'nty mrtxm'y ... ky' ZY ... L' ZK " zwnh yw'r ['krt](w) $\delta^{\prime} \mathrm{rt}$ ) 飞助けを求めることになることを説いているのだ と考学た。

48/21 : 'sp'xšt (H.), 'sp's'yt (Y.). 読みはH. のほらが優れている。しか 乙動詞の過去語幹は文脈からは意味をなさず，H. 自身もこれを“menial”と 翻訳している。'sp's'k と prm'n-ptrwš'k の組合せは，仏典にも在証される。 $B S T B L, 22$, line 63 参照。

\section{V.おわりに}

ソグド語を日本で研究する者として，日本に入ったソグド語資料の研究と公 表には責任感のようなものを感じている。私蔵に帰したものはともかく，公の 機関が保管するものだけでも公表できれば幸いである。な拈龍谷大学図書館蔵 の文書に関しては，既にカタログを作成し，あわせて特に重要な文書について 情録文と翻訳を付けて和いた。そこに含まれる全資料の写真之研究が，龍谷大 学の善本叢書の一冊として刊行されることになったことは望外の幸せである。

注

（1）本稿では東洋学の論文で通常用いられる略号以外に次のものが現われる:BST$B L=\mathrm{D}$. N. MacKenzie, The Buddhist Sogdian texts of the British Library, Acta Iranica 10, Tehran-Liège, 1976; GMS=I. Gershevitch, Grammar of Manichean Sogdian, Oxford, 1954; $\mathrm{P}=$ Pelliot sogdien, in: E. Benveniste, Textes sogdiens, Paris, 1940.

(2) 吉田豊「カラバルガスン碑文のソグド語版について」『西南アジア研究』No. 28, 1988, 52 頁参照。この機会に拙論の25頁の表にある重大な誤値を訂正しておきたい： 正しくはFr 5 の図版はXXXIVに，Fr6-9 の図版はXXXIII に見られる。なお 1994 年 7 月にモンゴル共和国で実地淍査された森安氏によれば，Fr 9 の位置は筆者が 想定したものではあり得ないとのことである。この発見は近い将来発表されるので, それを先取りすることはしない。 
（3）イラン語のものとしては, 別にマニ文字で書かれた大谷探検隊将来の文書の写真 る保管されている。この断片に関しては既に研究を発表した。Y. Yoshida, “On a Manichaean Middle Iranian fragment lost from the Otani collection” (崎山 理・佐藤昭裕（編）『アジアの諸言語と一般言語学』東京，三省堂，1990，175-81頁） 参照。

（4）この点は1983年に東京で開催された，国際東洋学者会議において口頭で発表した。 発表の要約は Proceedings of the thirty-first International Congress of Human Sciences in Asia and North Africa, Tokyo, 1984, 989-90 飞揭載されている。

（5）この断片とともに表装されているウイグル語文畫は，「吐魯番から出土し，曽て 新疆省に布政使として在任した王樹裡氏の手に帰したのであったが，その後転輾して 昨年（=1929年：筆者注）」京都大学東洋史研究室に入ったといら。『羽田博士史学論 文集 下巻』京都，1958，325頁参照。

（6）大谷探検隊将来の文書類のすべてが龍谷大学に入ったわけではない。例光ば筆者 がかつて発表したマ二文字文書の現在の所在は不明である。上記注 (3)参照。また同 一の文書の離れが，ベルリンのコレクションと大谷探検隊の将来物に分かれている例 も知られている。例觉ばソグド語文書では, 西域文化資料の 9133 号は, ベルリンの So 14842 と同一文書の離れである。この点は別に発表する予定である。

(7) W. B. Henning, “Sogdian tales”, in: BSOAS 11, 1945, 465-87 (特に 48587) 参照。

（8）この漢文文献についての研究は多いが，「歎無常文」の翻訳を含むのは次の 2 点 だけである: Tsui Chi, “Moni chiao hsia pu tsan”, BSOAS 11, 1943, 231-42; H. Schmidt-Glintzer, Chinesische Manichaica, Wiesbaden, 1987. 特飞後者は『大 正』のテキストに，写本での行数を添光てあるので便利である。

（9）この年代に関しては, 拙稿「大英図書館及びロシア科学アカデミー（サンクト・ ペテルブルグ支部）所蔵のソグド語文書について」（準備中）も参考にされたい。

（10）いくつかの難解な籄所について， ロンドン大学の N. Sims-Williams 教授から 有益な教示を得た。記して謝意を表す。なおこの文書にはウイグル語（17，23，24行 目）とシリア語（25行目）の書き込みがあるが，それらは筆者の手に負光ないので， ここでは扱わない。

（11）テキスト中の〔角括弧】は完全な破損部を表し，（丸括弧）は部分的な破損部で， 文字の一部が残っていることを示す。○は写本に見られる句読点である。

（12）訳文の中の[角括弧]は破損部を補ったものであり，（丸括弧）は訳文の日本語 を理解しやすくするために補った部分である。

（13）埋め草については Sims-Williams，JA 269，1981，350， n. 14 を参照。

（14）この動詞に関しては GMS, 309 参照。

（15）この動詞に関しては, D. Weber, Die Stellung der sog. Inchoativa im Mitteliranischen, Göttingen, 1970, 165 参照。 
（16）その場合現在語幹から二次的に派生したとするか（〈*daxs-ta-），*-s- によって 拡張された語根から派生したするか（〈*daxš-ta-）2つの可能性がある。 R. E. Emmerick, Saka grammatical studies, London, 1968, 43 参照。

(17) これらの動詞及び語根，さらには同源の諸語については Sims-Williams，BSOAS 42, 1979, 135 参照。

(18) Henning, JRAS 1944, 143 参照。

(19）ここで言及された巨人は，マニ教の 7 聖典のなかの『巨人の書』に登場する巨人 に違いない。『巨人の書』に関しては, Henning, BSOAS 11, 1943，52-74 参照。

(20) Henning, BSOAS 11, 1945, 469, n. 1 参照。

(21) GMS §369 参照。

(22) Schwartz, ZDMG 120, 302; M. Samadi, Das chwaresmische Verbum, Wiebaden, 1986, 171; MacKenzie, JRAS 1988, 197 参照。

（23）Schwartz，ibid. は，7番目に互いに殺し合って死んだものの肉が言及されてい るから，この例は「争う」ではあり得ないとするが，あまり強い反論ではない。原文 には殺害によらない肉を網羅的に，乙かも相互に過不足なく列挙しようとする意図が ないからである。

(24) $B S T B L, 42,11.145-46$ 参照。Benveniste は $\mathrm{rn}$ の意味を論じ “lutter, combattre”と解釈した際この例に触れたが, 異なる語と見なしていた。Textes sogdiens， Paris, 1940, 197 参照。一方 MacKenzie は Schwartz 飞も Benveniste にも言及 せず, “attack”と訳している。BSTBL，43 参照。ただし Benveniste, ihid.が同じ 語の異なる表記であると考えた rnp は，奴隷を虐待することを意味するので, rnßと は別の語と見なすべきであろう。吉田他『内陸アジア言語の研究』 N, 1988 [1989], 20 頁参照。

（25）ただ筆者にはこの様子が，Ibn Hawqal の伝えるサマルカンドの街角の彫刻と 酷似しているように思える：“Astonishing figures are cut out of cypresses, of horses, oxen, camels, and wild beasts; they stand one opposite the other, as though surveying each other and on the eve of engaging in a struggle or combat". W. Barthold, Turkestan down to the Mongol invasion, 2 nd ed., London, 1958, 91 参照。この比較が正しいなら，P 3 の例も「交尾する」とは訳せ ないことになる。

(26) K. Kudara and Sundermann, W., AoF 18, 1991, 250-51 参照。

(27) Sims-Williams, The Christian Sogdian manuscript C2, Berlin, 1985, 98 参 照。

(28）これはむしろ賄賂のようなものを指すのかもしれない。中世ペルシア語の文書 (M 727a, verso 4-6) に 'wd p'rg d'šn 'wd pdyst'wg'n ny pry'dynd pd h'n rwc 'y wdnng「賄賂も贈物も約束も，その苦しみの日には助けにならない」とある。 Henning, Transactions of the Philological Society, 1945, 152 参照。 
(29) Henning, JRAS 1944, 137-38 参照。

(30) この文書に関しては V. A. Livšic, Sogdijskie dokumenty s gory Mug, II, Moscow, 1962, 123 参照。

(31）拙稿『アジア・アフリカ言語文化研究』27，1984，83頁。拈よび Sims-Williams, op. cit., 55-56 参照。

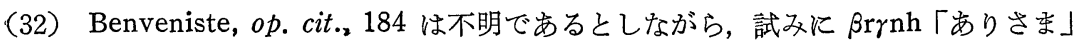
と比較しているが, 正しくない。

(33) Henning, BSOAS 11, 1943, 68 Text G, 8-9 参照。

(34) Henning, Ein manichäisches Bet- und Beichtbuch, APAW, 1936, Nr. 10, $51, \mathrm{f} 78-79$ 参照。

（35）ここでは šw は贈物や子供を奪われることになる人を指示しているはずであるか ら，結局とれは受動文の主語の役割を果たすことになる。最近 Sims-Williams は， 2 人称の冠詞及び代名詞の主格形 šw の存在を指摘しているが， 2 人称の要素はここ では期待されず，これをその例と見なすことはできないだろう。 Sims-Williams， "The triple system of deixis in Sogdian", in: Transactions of the Philological Society, Vol. 92, 1994, 41-53 参照。

(36)「諦」の字は解釈しにくい。あるいは「滞」の誤写と見なし，「この世にしばら くの間（共に）滞在する親族は……と解釈すべきだろらか。「世諦」を「この世の 真実 (die irdische Wahrheit)」と翻訳するのは如何なるのだろらか。H. SchmidtGlintzer, Chinesische Manichaica, Wiesbaden, 1987, 23 参照。

（37）筆者は文書の実物を見た際，愚かにも Henning の読みを確認し忘れた。幸いに も以前 R. E. Emmerick 教授は，ハンブルグにあるこの文書の写真を送って下さっ ていた。今回はこの写真を利用した。写真の利用を可能にして下さった Emmerick 教授及び A. Degener 博士に感謝する。

（38）百済康義・吉田豊 - W. Sundermann（編）『龍谷大学所蔵大谷探検隊収集中央 アジア出土イラン語断片目録』（科学研究費研究成果報告書）1993年 3 月参照。 

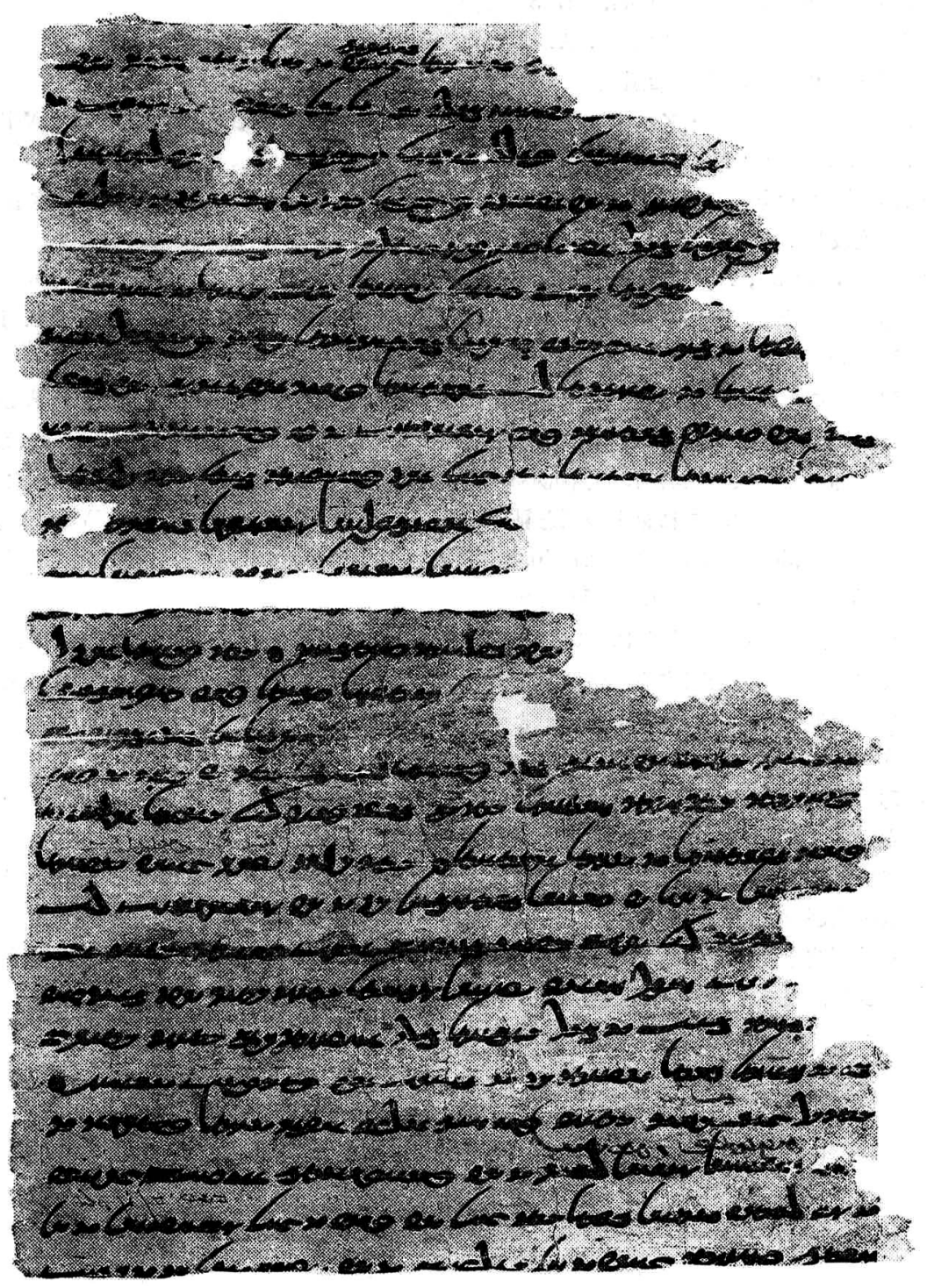

京都大学東洋史学科所蔵の写真からの複製 